Chapter 3.1

\title{
THE SARS CORONAVIRUS RECEPTOR ACE2 A POTENTIAL TARGET FOR ANTIVIRAL THERAPY
}

\author{
J. H. KUHN ${ }^{1,2}$, S. R. RADOSHITZKY ${ }^{1}$, W. LI $^{1}$, S. KEE WONG ${ }^{1}$, \\ H. $\mathrm{CHOE}^{3}$ and M. FARZAN ${ }^{1}$ \\ ${ }^{I}$ Department of Microbiology and Molecular Genetics, Harvard Medical School, New \\ England Primate Research Center, Southborough, MA, USA; ${ }^{2}$ Department of Biology, \\ Chemistry, Pharmacy, Freie Universität Berlin, Berlin, Germany; ${ }^{3}$ Department of Pediatrics, \\ Children's Hospital, Harvard Medical School, Boston, MA, USA
}

\begin{abstract}
In recent years, coronaviruses have received increasing attention from clinical infectious disease experts. The discovery of a coronavirus as the etiological agent of severe acute respiratory syndrome (SARS-CoV) and the identification of another coronavirus that causes upper respiratory tract diseases in children (HCoV-NL63) emphasized the importance of improving our understanding of these agents. The identification of angiotensin-converting enzyme 2 (ACE2), the cell-surface receptor for both SARS-CoV and HCoV-NL63, has opened the field for the development of new treatments and prophylactics. In this review, we describe the discovery of this coronavirus receptor and its interaction with coronaviral surface proteins in light of viral entry processes and host tropism.
\end{abstract}

\section{INTRODUCTION}

\section{$1.1 \quad$ Coronaviruses}

The viral order Nidovirales groups numerous viruses of vertebrates and invertebrates that share common characteristics such as genomic organization, transcription and replication strategies, and disease manifestations. Many of these viruses cause acute and chronic upper 
respiratory gastrointestinal, hepatic, and neurological diseases in both humans and animals (Enjuanes et al., 2000). The nidoviruses are compartmentalized into the three viral families Arteriviridae, Coronaviridae, and Roniviridae. Nidoviral pathogens that infect humans belong exclusively to the family Coronaviridae, which contains the two genera Coronavirus and Torovirus (Enjuanes et al., 2000).

Coronaviruses sensu stricto (viruses belonging to the genus Coronavirus rather than all members of the family Coronaviridae) are spherical to slightly pleomorphic viruses with a diameter of $100-160 \mathrm{~nm}$. The virions contain one copy of a 20-33kb-long capped and polyadenylated singlestranded RNA of positive polarity, which is helically encapsidated by nucleocapsid (N) proteins (Enjuanes et al., 2000). The filamentous ribonucleocapsids are surrounded by matrix (M) proteins, which form icosahedral cores. These cores are wrapped in envelopes formed during coronaviral budding from a host cell. The membranes contain distinct, clubor petal-shaped protrusions, identified as spike (S) proteins. It is those proteins that give the virions a crown-like appearance (Latin: coronae) in electron microscopic images (Enjuanes et al., 2000). S proteins are the major antigenic determinants of coronaviruses (Daniel et al., 1994; Gallagher et al., 2001; Koo et al., 1999; Moore et al., 1997; Song et al., 1998).

Coronaviruses attach to cell-surface receptors via their S proteins, which then mediate fusion with the host-cell membrane. Subsequently, a nested set of subgenomic RNAs is produced. Genome replication occurs in the cytoplasm and results in high-frequency recombination. After replication and maturation, coronaviruses bud from the endoplasmic reticulum-Golgi intermediate compartment (Enjuanes et al., 2000).

Three distinct genetic and serological groups of coronaviruses are acknowledged, but the grouping is undergoing revision (Gonzalez et al., 2003). Several coronaviruses are known to cause disease in humans. Human coronavirus 229E (HCoV-229E), a group 1 virus, and human coronavirus OC43 (HCoV-OC43), a group 2 virus, cause mild upper respiratory infections that result in self-resolving common colds in otherwise healthy individuals, or severe pneumonia in immunocompromised people (Denison, 1999; Pene et al., 2003). Human coronavirus NL63 (HCoV-NL63; also referred to as $\mathrm{HCoV}-\mathrm{NH}$ and $\mathrm{HCoV}-\mathrm{NL}$ ) has recently been identified as a group 1 virus causing conjunctivitis and sometimes serious respiratory infections in children (Esper et al., 2005b; Fouchier et al., 2004; van der Hoek et al., 2004). Epidemiological analyses suggest this virus to be associated with Kawasaki disease (Esper et al., 2005a). Another group 2 coronavirus (CoV-HKU1) was recently isolated from a 71-year old man with pneumonia (Woo et al., 2005). Several more pathogenic human 
coronaviruses (B814, HCoV-OC16, HCoV-OC37, and HCoV-OC48) await characterization (McIntosh, 2005).

\subsection{Severe acute respiratory syndrome virus}

Severe acute respiratory syndrome (SARS) was first described in November of 2002, when inhabitants of Guangdong Province, People's Republic of China, presented with an influenza-like illness that began with dyspnea, myalgia, and pyrexia, and was often followed by acute pneumonia, respiratory failure, and death (Peiris et al., 2003). The novel disease was transmitted via droplets and fomites and through direct contact of patients with uninfected individuals (Olsen et al., 2003; Yu et al., 2004). The outbreak spread all over Asia, Europe, and North America. At the end of the mini-pandemic in July 2003, a total of 8,096 cases had been recorded, of which 774 (9.6\%) had died (Cherry, 2004). A novel coronavirus, severe acute respiratory syndrome virus (SARS-CoV; species Severe acute respiratory syndrome coronavirus) was identified as the etiologic agent (Drosten et al., 2003; Fouchier et al., 2003; Ksiazek et al., 2003; Kuiken et al., 2003; Mayo, 2002). Molecular analyses demonstrated that SARS-CoV clusters with group 2 coronaviruses (Gibbs et al., 2004; Gorbalenya et al., 2004).

SARS reemerged in Guangdong Province in 2003-2004, when it infected four individuals, all of which recovered (Fleck, 2004; Song et al., 2005). All other cases recorded to date trace back to accidental laboratory infections. One and two nonfatal cases, respectively, were recorded in laboratories in the Republic of Singapore (Lim et al., 2004) and Taiwan (Normile, 2004) in 2003. The last cases occurred in 2004 in laboratories in Anhui Province (nine cases including one fatality) and in Beijing (two cases), People's Republic of China.

The natural reservoir of SARS-CoV remains elusive. Chinese ferretbadgers (Melogale moschata), Himalayan palm civets (Paguma larvata), and racoon dogs (Nyctereutes procyonoides) have been suggested as host candidates, because they carry SARS-CoV-like viruses (Guan et al., 2003). Domestic cats (Felis domesticus), ferrets (Mustela putorius furo), and Himalayan palm civets have been proposed as potential carriers because they are susceptible to SARS-CoV infection and because they can transmit the agent (Martina et al., 2003; Wu et al., 2005). BALB/c mice (Subbarao et al., 2004; Wentworth et al., 2004), hamsters (Roberts et al., 2005), and cynomolgus and rhesus macaques (Rowe et al., 2004) are currently being used as animal models for SARS-CoV infection. 
As of today, vaccines have not been approved for the prevention of human SARS-CoV infections, although several candidates are clinically evaluated.

Sera obtained from SARS survivors contain high titers of SARS-CoVneutralizing antibodies. SARS patients were reported to clinically improve after the administration of such reconvalescent sera (Li et al., 2003a; Pearson et al., 2003). Neutralizing antibodies, administered to $\mathrm{BALB} / \mathrm{c}$ mice intraperitoneally one day before intranasal challenge with $10^{4} 50 \%$ tissue culture infective doses $\left(\mathrm{TCID}_{50}\right)$ of the SARS-CoV Urbani strain, reduced viral load by four orders of magnitude (Sui et al., 2005). These data suggest that antibodies could be used to prevent and treat SARS, and also that the development of a SARS vaccine is plausible. Promising results in vaccine development have been obtained with inactivated whole virus (He et al., 2004b; Takasuka et al., 2004), recombinant $\mathrm{N}$ or S protein administered either as a DNA vaccine (Yang et al., 2004; Zhao et al., 2005), via replicationdeficient adenoviruses (Zakhartchouk et al., 2005) or Lactococcus lactis (Pei et al., 2005), as well as via $\mathrm{S}$ protein-expressing vaccinia viruses (Bisht et al., 2004; Chen et al., 2005). In all these cases, development of neutralizing antibodies was reported after immunization, and in the majority, these vaccines protected mice from challenge with infectious SARS-CoV. However, mice do not develop a SARS-like disease after viral infection. SARS-CoV infection only leads to high levels of replication in their respiratory tracts, and virus is cleared within seven days post infection (Subbarao et al., 2004). Hence, it remains unclear whether the vaccine candidates tested would also be efficacious in primates or, later, in humans. Studies in nonhuman primates have been sparse, but at least one group achieved protection of African green monkeys (Chlorocebus aethiops) against SARS-CoV challenge after vaccination with an attenuated parainfluenza virus expressing SARS-CoV S protein (Bukreyev et al., 2004).

Obvious targets for antiviral agents include the SARS-CoV protease, mRNA cap-1 methyl-transferase, NTPase/helicase, and the transcriptasereplicase complex. However, with the exception of interferons, which have been shown effective in inhibiting SARS-CoV replication in tissue cultures, no clinically approved antiviral drug could be identified for the treatment of SARS so far (Tan et al., 2004).

\subsection{Coronaviral spike proteins and host-cell receptors}

The host spectrum and virulence of a specific coronavirus is largely determined by its S protein (Kuo et al., 2000; Phillips et al., 1999; Sanchez et al., 1999). Coronaviral S proteins measure 12-24 $\mathrm{nm}$ in length. They are spaced widely apart, and are evenly distributed all over the surface of the 
coronavirion (Enjuanes et al., 2000). They are type I transmembrane and class I fusion proteins (Bosch et al., 2003; Gallagher, 2001), and consist of distinct N-terminal (S1) and C-terminal (S2) domains, which mediate receptor binding and virus-cell fusion, respectively (Gallagher, 2001). Upon binding of the cell-surface receptor, a conformational change of the S1 domain induces the exposure of a fusion peptide embedded in the S2 domain, which then induces the reorganization of S2's unusually large heptad repeats into coiled-coils. This extreme conformation switch forces the virion membrane into close apposition to the cell membrane and allows fusion and hence penetration of the viral core into the cell (Colman et al., 2003; Dimitrov, 2004; Lai et al., 1997).

Only few coronavirus cell-surface receptors have been identified. Aminopeptidase N (APN, CD13) was shown to be the receptor for canine coronavirus, feline infectious peritonitis virus, HCoV-229E, porcine epidemic diarrhea virus, and porcine transmissible gastroenteritis virus, all of which are group 1 coronaviruses (Delmas et al., 1992; Oh et al., 2003; Yeager et al., 1992). Members of the pleiotropic family of carcinoembryonic antigen-cell adhesion molecules were identified as receptors for the group 2 pathogen murine hepatitis virus (Williams et al., 1991), whereas bovine group 2 coronaviruses bind to 9- $O$-acetylated sialic acids (Holmes et al., 1994).

\section{IDENTIFICATION OF ACE2 AS THE RECEPTOR OF SARS CORONAVIRUS AND HUMAN CORONAVIRUS NL63}

Full-length and partial S proteins of different SARS-CoV isolates were cloned, expressed, and characterized by several research groups only months after the discovery of the virus (Babcock et al., 2004; Bisht et al., 2004; Li et al., 2003b; Simmons et al., 2004; Wong et al., 2004; Xiao et al., 2003). SARS-CoV S protein was found to have a molecular weight of about $170-200 \mathrm{kD}$ in PAGE analyses. The protein was suggested to undergo posttranslational modifications since the determined weight was much higher than the molecular weight predicted from the amino acid sequence (Bisht et al., 2004; Xiao et al., 2003). SARS-CoV S protein is a typical class I fusion protein. However, there is little (20-27\%) similarity between the amino acid sequence of $\mathrm{S}$ protein of SARS-CoV and those of other coronaviral S proteins (Rota et al., 2003). Furthermore, in contrast to most other S proteins, SARS-CoV S protein is not cleaved by a host cell protease into S1 and S2 subunits, although domains corresponding to S1 and S2 have been identified (Marra et al., 2003; Rota et al., 2003; Xiao et al., 2003). 
SARS-CoV S protein alone is sufficient to mediate virus-cell fusion. The SARS-CoV S1 domain was identified as the receptor-binding region of the attachment protein, whereas the S2 domain was found to mediate fusion with the host cell membrane (Li et al., 2003b; Xiao et al., 2003). However, it was impossible to predict which cell-surface receptor SARS-CoV might utilize to fuse with host cells, in part because of the limited sequence homology between the SARS-CoV S1 domain and the S1 proteins of other coronaviruses. In fact, the observed severity and lethality of SARS-CoV infections and the elucidated limited S1 sequence homology with other S proteins suggested a receptor different from all other known coronavirus receptors.

Our laboratory employed a straight-forward approach, coimmunoprecipitation, to identify the SARS-CoV cell surface receptor (Li et al., 2003b). We first created a codon-optimized gene encoding the SARS-CoV Urbani strain S1 domain (amino acid residues 12-672) fused to the Fc domain of human IgG1 (S1-Ig). Codon optimization resulted in markedly enhanced expression levels compared to wild-type $\mathrm{S}$ protein (Moore et al., 2004). The construct bound to the surface of African green monkey kidney (Vero E6) cells, which are highly susceptible to SARS-CoV infection, with high affinity, but not to human embryonic kidney (HEK 293T) cells, in which SARS-CoV replicates poorly (Li et al., 2003b). Encouraged by this observation, we lysed metabolically labelled Vero E6 cells with a detergent $(0.3 \% n$-decyl- $\beta$-D-maltopyranoside in PBS), and incubated the lysate with SARS-CoV S1-Ig and Sepharose-Protein A beads. Bound proteins were separated by PAGE, and individual bands, which were not present in control reactions, were analyzed by trypsin digestion and mass spectrometry. We identified a promising SARS-CoV receptor candidate, the $110 \mathrm{kD}$ human angiotensin-converting enzyme 2 (ACE2) (Li et al., 2003b). A soluble form of ACE2, but not of the closely related ACE1, blocked binding of S1-Ig to the surface of Vero E6 cells. Antibodies to ACE2, but not those to ACE1, blocked SARS-CoV (strain Urbani) replication in Vero E6 cells. SARS-CoV replicated more efficiently in HEK 293T cells after ACE2 transfection. Last, we demonstrated syncytia formation between $S$ protein-expressing HEK 293T cells and HEK 293T cells expressing ACE2 (Li et al., 2003b), suggesting that the syncytia observed in SARS-CoV-infected Vero E6 cells, nonhuman primates, and patients (Drosten et al., 2003; Fouchier et al., 2003; Kuiken et al., 2003) develop through $\mathrm{S}$ protein-ACE2 interactions. Commercially available antibodies targeting ACE2 blocked syncytia formation (Li et al., 2003b). Stably ACE2-expressing HEK 293T cells were more transducible with $\mathrm{S}$ protein-pseudotyped simian immunodeficiency virus than VeroE6 cells (Moore et al., 2004), which is consistent with the idea that the abundance of ACE2 on the cell surface determines the 
efficiency of SARS-CoV infection. Others have identified a recombinant human single-chain variable region fragment (scFV) against the SARS-CoV (strain TOR2) S1 domain from nonimmune human antibody libraries. This scFV (named 80R scFV) not only inhibited the formation of syncytia between HEK 293T cells expressing ACE2 and HEK 293T cells expressing the $\mathrm{S}$ protein, but also efficiently neutralized infection of Vero E6 cells with the SARS-CoV Urbani strain. 80R scFV competed with a soluble form of ACE2 for association with the S1 domain, and was found to bind S1 with high affinity $\left(\mathrm{K}_{\mathrm{d}}=32.3 \mathrm{nM}\right)$ in plasmon resonance studies. A human IgG1 form of $80 \mathrm{R}$ scFV $(80 \mathrm{R})$ bound $\mathrm{S} 1$ with higher affinity $\left(\mathrm{K}_{\mathrm{d}}=1.59 \mathrm{nM}\right)$ and neutralized the Urbani strain of SARS-CoV with a 20 -fold higher efficiency than $80 \mathrm{R} \mathrm{scFV}$ (Sui et al., 2004). ACE2 was also independently identified as a SARS-CoV receptor by another group, which transduced HeLa cells with a retrovirus cDNA library from Vero E6 cells, followed by flow cytometry to select transduced cells that bound to purified S protein (residues 14-502) (Wang et al., 2004).

ACE2, a carboxy-metalloprotease not related to any other coronavirus receptor but distantly related to ACE, was discovered in 2000 (Donoghue et al., 2000; Tipnis et al., 2000). The enzyme is a type I transmembrane protein with a single metalloprotease active site with a HEXXH zinc binding motif. (Donoghue et al., 2000; Tipnis et al., 2000). The physiological function of ACE2 remains enigmatic. The enzyme has been shown to cleave a variety of regulatory peptides in vitro, among them angiotensin I and II, des-Arg-bradykinin, kinetensin, and neurotensin (Donoghue et al., 2000; Vickers et al., 2002). Some cleavage products have been shown to be potent vasodilators with antidiuretic effects. This finding gave rise to the theory that ACE2 counterbalances the actions of ACE1, which mediates vasoconstriction (Yagil et al., 2003). Furthermore, targeted disruption of ACE2 in mice resulted in severe cardiac contractility defects (Crackower et al., 2002).

Despite high expression levels of ACE2, only low levels of SARS-CoV replication were found in cardiac tissue (Farcas et al., 2005). This finding suggested that another receptor or a coreceptor is necessary for successful cellular infection with SARS-CoV. Indeed, CD209L (DC-SIGNR, L-SIGN) has been identified as a molecule that can facilitate SARS-CoV infection (Jeffers et al., 2004; Marzi et al., 2004). However, the tissue distribution of ACE2 matches the tissue tropism of SARS-CoV. For example, high levels of ACE2 expression were detected in the gastrointestinal tract, kidneys, and lungs (Ding et al., 2004; Donoghue et al., 2000; Hamming et al., 2004; Harmer et al., 2002), all of which are targets of SARS-CoV (Hamming et al., 2004). Others have shown that the level of ACE2 expression in different cell lines correlates with their susceptibility for SARS-CoV infection 
(Hattermann et al., 2005; Hofmann et al., 2004) or their susceptibility for transduction with lentiviral pseudotypes carrying SARS-CoV S proteins (Nie et al., 2004). Transfection of ACE2 into SARS-CoV-refractory cell lines conferred susceptibility to infection (Mossel et al., 2005).

Taken together, these results imply that ACE2 is the major cell-surface receptor for SARS-CoV. They also suggest that tissues, which express ACE2 but are rather refractory to SARS-CoV infection, limit virus replication at a step following the interaction of the S protein with ACE2.

We and others also determined the receptor-binding domain (RBD) of SARS-CoV S1 (Babcock et al., 2004; Wong et al., 2004), which consists of only 193 amino acids (S1 residues 318-510; see Figure 1).

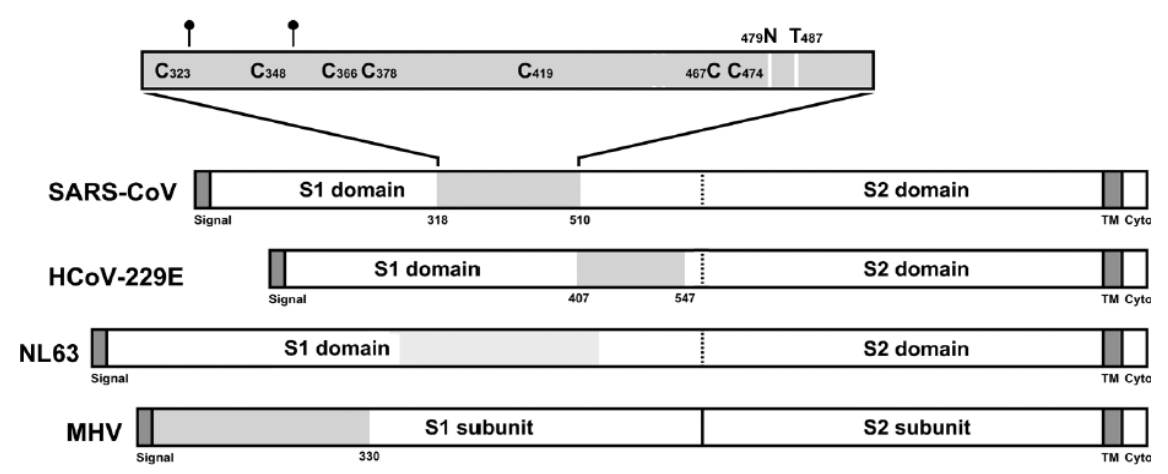

Figure 1: Receptor-binding domains of coronaviruses. Representation of the $\mathrm{S}$ proteins of SARS-CoV, HCoV-229E, HCoV-NL63 (NL63), and mouse hepatitis virus (MHV), aligned by their S2 domains. Dark gray indicates leader and transmembrane sequences. Light gray indicates receptor-binding domain. Future experiments may define the receptor-binding domain of NL63 more precisely than what is indicated. The receptor-binding domain of SARS-CoV is shown with N-glycosylation sites (small circles) and cysteines indicated. Residues that are critical to the high affinity interaction of SARS-CoV with human ACE2 (asparagine 479 and threonine 487) are shown as white bars.

An IgG1 Fc fusion protein (RBD-Ig) bound ACE2 more efficiently than full-length S1-Ig (Wong et al., 2004). At least two amino acid residues (glutamic acid 452 and aspartic acid 454) are crucial for S1-ACE2 interaction (Wong et al., 2004). In HEK 293T cells stably expressing ACE2, RBD-Ig blocked transduction of cells with $\mathrm{S}$ protein-pseudotyped simian immunodeficiency virus at a lower concentration $\left(\mathrm{IC}_{50}=10 \mathrm{nM}\right)$ than fulllength $\mathrm{S} 1-\mathrm{Ig}\left(\mathrm{IC}_{50}=50 \mathrm{nM}\right)$ (Wong et al., 2004). RBD-Ig in combination with Freund's complete adjuvant induced strong antibody responses in intradermally immunized NZW rabbits. These antibodies completely inhibited infection of Vero E6 cells with 100 TCID $_{50}$ SARS-CoV at a serum dilution 
of 1:10,240, and blocked the interaction of S1 with commercially available ACE2 (He et al., 2004a). Similarly, the immunization of mice and rabbits with inactivated SARS-CoV induced antibodies that specifically recognize the RBD, block S1-RBD interaction, and prevent cell transduction with $\mathrm{S}$ protein-pseudotyped HIV-1 (He et al., 2004b). Attenuated modified vaccinia virus Ankara expressing the SARS-CoV HKU38849 strain S protein induced neutralizing antibodies in immunized BALB/c mice, rabbits, and Chinese rhesus macaques. The antibodies were demonstrated to recognize a neutralizing epitope consisting of S protein's amino acid residues 400-600. This strongly suggested that the RBD was targeted by the antibodies. In fact, RBD-Ig could absorb the majority of neutralizing antibodies after incubation with antibody-containing sera (Chen et al., 2005). Finally, the conformationally sensitive epitope recognized by the potent SARS-CoV-neutralizing antibody 80R (Sui et al., 2004) was identified in $\mathrm{S}$ protein's N-terminal amino acid residues 324-503, which overlap the $\mathrm{RBD}$, and $80 \mathrm{R}$ scFV precipitated RBD-Ig as efficiently as protein A (Sui et al., 2005). Combined, these results strongly support the idea that SARS-CoV neutralizing antibodies target the receptor-binding domain of S protein and that virus neutralization occurs mainly through the interruption of the S1-ACE2 interaction.

Deletion studies demonstrated that the cytoplasmic domain of ACE2 is not important for ACE2-S1 interaction. Additionally, soluble ACE2 consisting only of its ectodomain blocked transduction with $\mathrm{S}$ proteinpseudotyped HIV-1 (Hofmann et al., 2004). We demonstrated that an enzymatically inactive ACE2 variant, which contains two asparagine residues in place of the active-site histidine residues (ACE2-NN-Ig), still binds $\mathrm{S}$ protein and facilitates entry of $\mathrm{S}$ protein-pseudotyped lentiviruses. This finding demonstrated that the proteolytic activity of ACE2 plays no role in SARS-CoV cell penetration (Moore et al., 2004). Also, binding of the S protein to ACE2 did not alter ACE2's enzymatic activity (Li et al., 2005; Moore et al., 2004). Finally, we showed that purified ACE2-NN-Ig prevented HEK 293T cell transduction with S-protein-pseudotyped simian immunodeficiency virus $\left(\mathrm{IC}_{50}=2 \mathrm{nM}\right)$, and that it blocked infection of VeroE6 cells with infectious SARS-CoV (Moore et al., 2004).

The SARS-CoV-neutralizing antibody 80R blocked HEK 293T cell transduction with HIV-1 pseudotypes carrying the SARS-CoV strain TOR2 or strain SZ3 S proteins, but did not prevent transduction with pseudotypes carrying the strain GD03T0013 S protein (Sui et al., 2005). This observation implied that the RBDs differ in key residues and suggested the possibility that different RBDs have different affinities to ACE2 of different species. A comparison of the RBD amino acid sequences of reported distinct SARS- 
SARS-CoV isolates and SARS-CoV-like viruses from Himalayan palm civets revealed only few amino acid changes (see Table 1) (Sui et al., 2005).

Table 1. Amino acid changes in the receptor binding domains (RBDs) of the spike (S) proteins of various SARS-CoV or SARS-CoV-like isolates according to (Sui et al., 2005)

\begin{tabular}{|l|l|l|l|l|l|l|l|l|}
\hline $\begin{array}{l}\text { SARS- } \\
\text { CoV } \\
\text { isolate }\end{array}$ & Origin & $\begin{array}{l}\text { GenBank } \\
\text { accession } \\
\text { No. }\end{array}$ & $\begin{array}{l}\text { Amino } \\
\text { acid at } \\
\text { positio } \\
\mathbf{n ~ 3 4 4}\end{array}$ & $\begin{array}{l}\text { Amino } \\
\text { acid at } \\
\text { positio } \\
\text { n 360 }\end{array}$ & $\begin{array}{l}\text { Amino } \\
\text { acid at } \\
\text { positio } \\
\text { n 472 }\end{array}$ & $\begin{array}{l}\text { Amino } \\
\text { acid at } \\
\text { position } \\
\mathbf{4 7 9}\end{array}$ & $\begin{array}{l}\text { Amino } \\
\text { acid at } \\
\text { positio } \\
\text { n 480 }\end{array}$ & $\begin{array}{l}\text { Amino } \\
\text { acid at } \\
\text { positio } \\
\text { n 487 }\end{array}$ \\
\hline GD01 & $\begin{array}{l}\text { Early } \\
\text { phase } \\
2002-2003\end{array}$ & $\begin{array}{l}\text { AY27848 } \\
9\end{array}$ & R/K & F & L & N & D & T \\
\hline $\begin{array}{l}\text { TOR2 } \\
\text { Middle/ } \\
\text { Late phase } \\
2002-2003\end{array}$ & $\begin{array}{l}\text { AY27411 } \\
9\end{array}$ & K & F & L & N & D & T \\
\hline $\begin{array}{l}\text { SZ3 } \\
\text { (SARS } \\
\text {-CoV- } \\
\text { like) }\end{array}$ & $\begin{array}{l}\text { Himalayan } \\
\text { palm civet }\end{array}$ & $\begin{array}{l}\text { AY30448 } \\
6, \\
\text { AY88117 }\end{array}$ & R & S & L & K & D & S \\
\hline $\begin{array}{l}\text { GD } \\
\text { 03T00 } \\
13\end{array}$ & $2003-2004$ & $\begin{array}{l}\text { AY52563 } \\
6\end{array}$ & R & S & P & N & G & S \\
\hline
\end{tabular}

The tissue distribution of murine and rat ACE2 was found to be comparable to that of human ACE2 (Gembardt et al., 2005; Komatsu et al., 2002). However, we found that murine ACE2 bound less efficiently to the SARS-CoV S1 domain and supported S protein-mediated infection less efficiently than human ACE2. Likewise, HEK 293T cell syncytia formation occurred at much higher efficiency when human ACE2, rather than murine ACE2, was expressed. Murine NIH 3T3 cells expressing human ACE2 supported SARS-CoV replication at a level of one magnitude higher than cells expressing murine ACE2. Rat ACE2, on the other hand, did not support $\mathrm{S}$ protein-mediated infection nor HEK 293T cell syncytia formation. (Li et al., 2004). Interestingly, the exchange of only four amino acid residues of rat ACE2 for the equivalent residues found in human ACE2 (residues 82-84 and 353) transformed rat ACE2 into an efficient receptor for the SARS-CoV S1 domain (Li et al., 2005). 

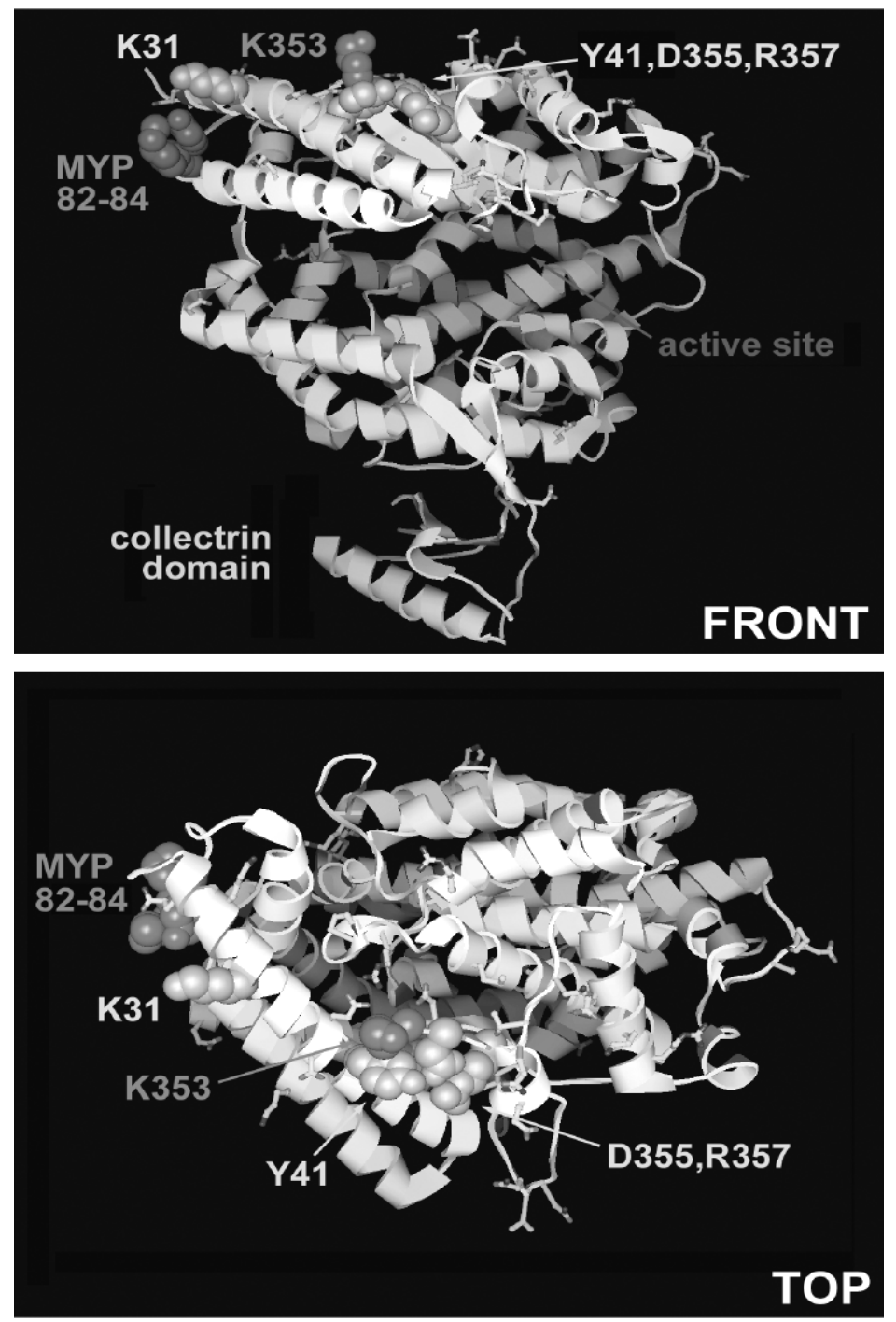

Figure 2: The S protein-binding site on human ACE2. (Upper panel) The crystal structure of ACE2 is shown, oriented with the C-terminal "collectrin" domain downward and viewed from the front of the cleft bearing the enzymatic active site. Residues of rat ACE2 whose alteration to the corresponding human residues converted rat ACE2 to an efficient SARS-CoV receptor are shown in dark gray spheres. Human ACE2 residues whose alteration substantially decreased S1-Ig association are shown in light gray spheres. Residues whose alteration did not affect S1-Ig association are shown in stick figure format. Low-resolution electron density associated with the collectrin domain is represented by a small $\beta$-sheet and $\alpha$-helix at the base of the figure. (Lower panel) A view identical to that in in Upper panel except that the molecule has been rotated 90 degrees about the horizontal axis to present a "virus-eye" view of ACE2. 
The findings led us to hypothesize that the host tropism of SARS-CoV and SARS-CoV-like viruses, as well as the severity of induced disease in different species might be dependent on RBD and ACE2 mutations. Experiments from our laboratory support this hypothesis. As shown in Figure 2, we localized the S protein-binding domain of ACE2 to $\alpha$-helix 1 and to a loop of $\beta$-sheet 5 (Li et al., 2005), both of which are located afar from the enzyme's active site but within the catalytic domain (Dales et al., 2002; Towler et al., 2004). S proteins from the different SARS-CoV strains isolated during the 2002-2003 and the 2003-2004 outbreaks as well as $\mathrm{S}$ proteins from the SARS-CoV-like viruses isolated from Himalayan palm civets bound to Himalayan palm civet ACE2 efficiently. However, as shown in Figure 3, the latter two proteins bound to human ACE2 much less efficiently than the $\mathrm{S}$ protein of the virus causing the initial 2002-2003 outbreak (Li et al., 2005). Exchanging specific residues of human ACE2 for those found in Himalayan palm civet ACE2 markedly enhanced binding of the $\mathrm{S}$ proteins of the 2003-2004 and Himalayan palm civet viruses. Likewise, exchanging residues 479 and 487 of these S protein's RBDs for residues found in the $S$ protein of virus isolates from the 2002-2003 outbreak (see Table 1) increased the binding efficiency to human ACE2 (Li et al., 2005). Collectively, these data suggest that the apparent lack of severity and human-to-human transmission associated with the small SARS outbreak in 2003-2004 is in part due to incomplete adaptation of the associated virus isolate to human ACE2, and that this adaptation is mediated mainly by two amino acid residues. These results also provide biochemical support for the hypothesis that the palm civet was a source of SARS-CoV.

The tissue tropism of human coronavirus NL63 (HCoV-NL63) and SARS-CoV seems to be identical. Recently, using HIV-1 pseudotypes, it was shown that HCoV-NL63 also uses ACE2 as a cell-entry receptor, albeit with lower affinity (Hofmann et al., 2005). This finding is surprising because the spike proteins of the two viruses share no amino acid identity. Additionally, this finding suggests that SARS is caused by an unidentified virulence factor of SARS-CoV, which is not encoded by the relatively harmless HCoV-NL63 genome. Clearly, further studies of the HCoV-NL63 entry mechanism are necessary. (Hofmann et al., 2005) 

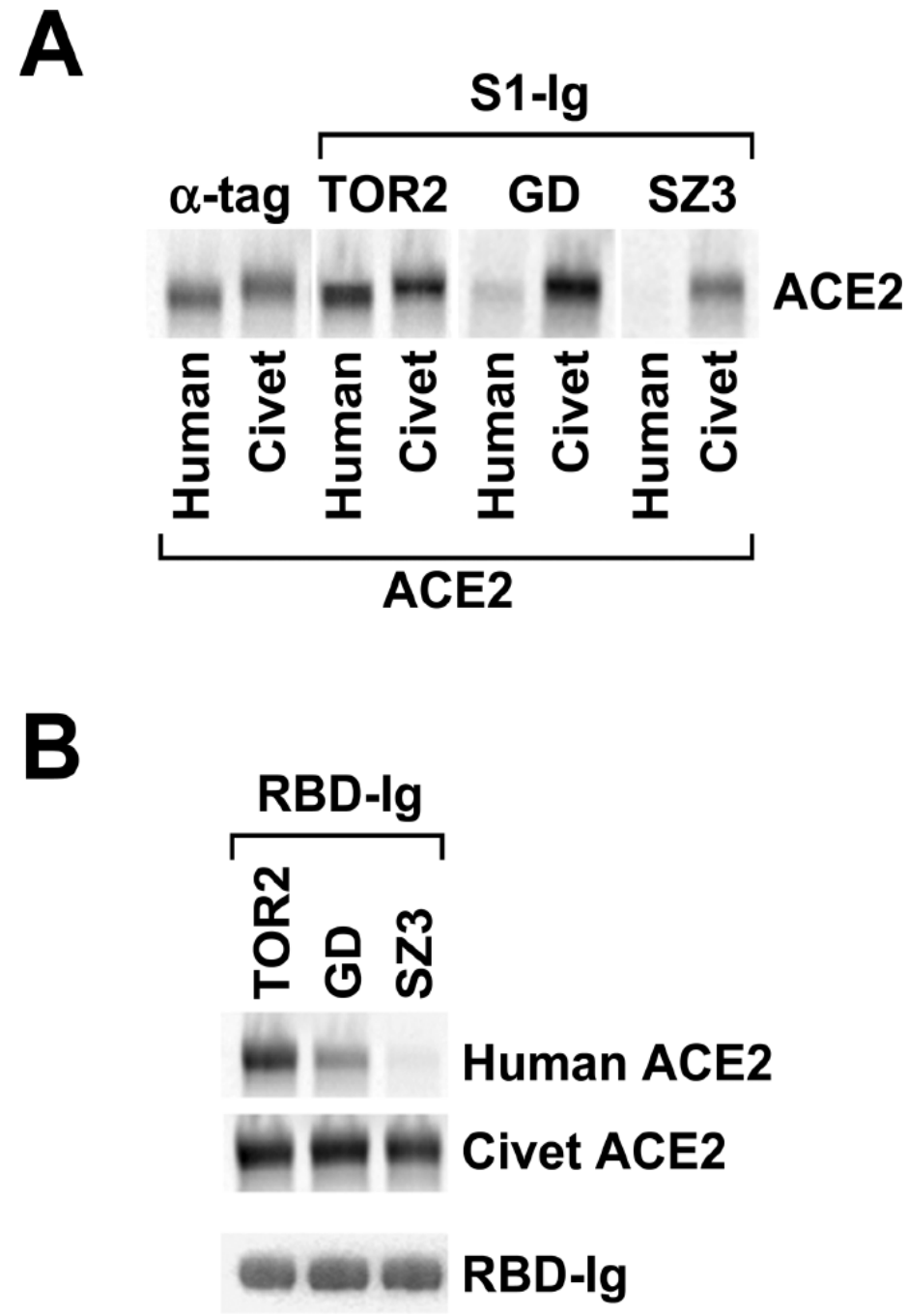

Figure 3: Differential association of three S proteins with human and palm-civet ACE2. (A) 293 T cells were transfected with plasmids encoding human or palm-civet ACE2, radiolabeled, and lysed. ACE2 proteins were immunoprecipitated with an antibody, which recognizes a tag present at the carboxy-terminus of each receptor, or with S1-Ig variants containing the S1 domains of TOR2, GD, or SZ3 S proteins, and analyzed by SDS-PAGE. TOR2 SARS-CoV was isolated from humans infected during the 2002-2003 outbreak; GD, from a small outbreak in 2003-2004 which resulted in mild symptoms and no human-to-human transmission; and SZ3, from palm civets. (B) An experiment similar to that in (A) except that S-protein residues 318-510, comprising the receptor-binding domains (RBDs) of the indicated $\mathrm{S}$ proteins fused to the Fc domain of human IgG1 (RBD-Ig), were used to immunoprecipitate human or palm-civet ACE2. The bottom panel shows a Coomassie-stained SDS-PAGE gel of the individual RBDs used in this experiment. 


\section{CONCLUSIONS}

During its first recognized appearance in 2002, SARS-CoV quickly spread globally among human populations, and caused a novel severe disease in more than 8,000 people with a lethality of almost $10 \%$ (Cherry, 2004). Only one natural outbreak of SARS has been recorded since. During this emergence, only four people were infected and all survived (Fleck, 2004). This gave rise to the notion that SARS-CoV has disappeared; that future outbreaks of SARS are not likely; and that research funds would be better spent on other pathogens. However, the natural reservoir of SARS$\mathrm{CoV}$ still has to be identified. Himalayan palm civets are suspected to be carriers of the virus, and these animals were associated epidemiologically with many, but not all, human SARS cases. In experiments, Himalayan palm civets were shown to be susceptible to SARS-CoV infection and replication. However, other animals like domestic cats and ferrets were also shown to be susceptible (Martina et al., 2003; Wu et al., 2005); and Chinese ferret badgers and racoon dogs were suggested as natural carriers of SARS-CoVlike viruses (Guan et al., 2003). Our experiments demonstrated that only two amino acid residues of the receptor binding domain of SARS-CoV spike protein determine its efficiency to bind to its cell-surface receptor, ACE2. These two residues are variable in different animals and hence allow or prohibit SARS-CoV cell entry (Li et al., 2005). This finding suggests that only few mutations need to occur in a naturally circulating SARS-CoV or SARS-CoV-like virus in the unknown reservoir to allow for cross-species transmission and further human SARS outbreaks. On the other hand, experiments performed in our and other laboratories also suggest that specific prevention and treatment of these SARS outbreaks could be achievable. In this review, we have presented strong support for the role of ACE2 as the sole cell-entry determinant of SARS-CoV, and we described the ability of neutralizing antibodies to disrupt the S-ACE2 interaction (Hattermann et al., 2005; Li et al., 2003b; Mossel et al., 2005; Nie et al., 2004; Sui et al., 2004; Wang et al., 2004). These results suggest that future vaccine candidates should elicit antibody responses to the $\mathrm{S}$ protein receptor binding domain. In terms of treatment, several promising research directions could be taken. First, based on our findings that the SARS-CoV S protein receptor binding domain can prevent cell transduction with $\mathrm{S}$ proteinpseudotyped lentiviruses (Wong et al., 2004), modified polypeptides resembling S protein fragments could be developed to bind to ACE2 and prevent binding of SARS-CoV to its host cells. Second, the development of specific inhibitors of ACE2, which do not contain S protein fragments, is feasible. For example, the identification of an inhibitor, which prevents binding of SARS-CoV to ACE2 and ACE2 proteolytic activity, was recently 
reported (Huentelman et al., 2004). However, this inhibitor is most likely associated with severe side effects since it interrupts ACE2's physiological, as of yet unknown, function. We demonstrated that SARS-CoV binds to ACE2 at a site remote of the enzyme's active site (Li et al., 2005), and we showed further that SARS-CoV binding does not interfere with ACE2's enzymatic activity (Li et al., 2005; Moore et al., 1997). Hence, better inhibitors could be identified, which only block S-ACE2 interaction but do not alter the physiological function of ACE2. Last, it has been shown that soluble ACE2 can prevent transduction of ACE2-expressing cells with SARS-CoV S protein-pseudotyped lentiviruses (Hofmann et al., 2004; Li et al., 2005), suggesting that a polypeptide consisting of the SARS-CoVbinding domain of ACE2 could be used as a therapeutic. We have shown that enzymatically inactive ACE2 is still able to interrupt $\mathrm{S}$ protein-mediated entry of lentiviral pseudotypes (Moore et al., 2004). This should allow for the synthesis of ACE2 variants or fragments thereof, which would prevent SARS-CoV infection but would not interfere with the predicted role of ACE2 as a regulator of blood pressure (Yagil et al., 2003).

The surprising discovery of ACE2 as a receptor of another coronavirus, $\mathrm{HCoV}-\mathrm{NL} 63$, raises the question whether antivirals or vaccines could be developed, which target both this virus and SARS-CoV at the same time. Evidently, it is necessary to define the receptor-binding domain of $\mathrm{HCoV}$ NL63's spike protein and the interacting region of ACE2 to find an answer.

\section{REFERENCES}

Babcock, G. J., Esshaki, D. J., Thomas, W. D., Jr. and Ambrosino, D. M., 2004, Amino acids $270-510$ of the severe acute respiratory syndrome coronavirus spike protein are required for interaction with the receptor. J. Virol. 78:4552-4560

Bisht, H., Roberts, A., Vogel, L., Bukreyev, A., Collins, P. L., Murphy, B. R., Subbarao, K. and Moss, B., 2004, Severe acute respiratory syndrome coronavirus spike protein expressed by attenuated vaccinia virus protectively immunizes mice. Proc. Natl. Acad. Sci. USA 101:6641-6646

Bosch, B. J., van der Zee, R., de Haan, C. A. and Rottier, P. J., 2003, The coronavirus spike protein is a class I virus fusion protein: structural and functional characterization of the fusion core complex. J. Virol. 77:8801-8811

Bukreyev, A., Lamirande, E. W., Buchholz, U. J., Vogel, L. N., Elkins, W. R., St Claire, M., Murphy, B. R., Subbarao, K. and Collins, P. L., 2004, Mucosal immunisation of African green monkeys (Cercopithecus aethiops) with an attenuated parainfluenza virus expressing the SARS coronavirus spike protein for the prevention of SARS. Lancet 363:2122-2127 
Chen, Z., Zhang, L., Qin, C., Ba, L., Yi, C. E., Zhang, F., Wei, Q., He, T., Yu, W., Yu, J., Gao, H., Tu, X., Gettie, A., Farzan, M., Yuen, K. Y. and Ho, D. D., 2005, Recombinant modified vaccinia virus Ankara expressing the spike glycoprotein of severe acute respiratory syndrome coronavirus induces protective neutralizing antibodies primarily targeting the receptor binding region. J. Virol. 79:2678-2688

Cherry, J. D., 2004, The chronology of the 2002-2003 SARS mini pandemic. Paediatr. Respir. Rev. 5:262-269

Colman, P. M. and Lawrence, M. C., 2003, The structural biology of type I viral membrane fusion. Nat. Rev. Mol. Cell Biol. 4:309-319

Crackower, M. A., Sarao, R., Oudit, G. Y., Yagil, C., Kozieradzki, I., Scanga, S. E., Oliveirados-Santos, A. J., da Costa, J., Zhang, L., Pei, Y., Scholey, J., Ferrario, C. M., Manoukian, A. S., Chappell, M. C., Backx, P. H., Yagil, Y. and Penninger, J. M., 2002, Angiotensinconverting enzyme 2 is an essential regulator of heart function. Nature 417:822-828

Dales, N. A., Gould, A. E., Brown, J. A., Calderwood, E. F., Guan, B., Minor, C. A., Gavin, J. M., Hales, P., Kaushik, V. K., Steward, M., Tummino, P. J., Vickers, C. S., Ocain, T. D. and Patane, M. A., 2002, Substrate-based design of the first class of angiotensinconverting enzyme-related carboxypeptidase (ACE2) inhibitors. J. Am. Chem. Soc. 124:11852-11853

Daniel, C., Lacroix, M. and Talbot, P. J., 1994, Mapping of linear antigenic sites on the S glycoprotein of a neurotropic murine coronavirus with synthetic peptides: a combination of nine prediction algorithms fails to identify relevant epitopes and peptide immunogenicity is drastically influenced by the nature of the protein carrier. Virology 202:540-549

Delmas, B., Gelfi, J., L'Haridon, R., Vogel, L. K., Sjostrom, H., Noren, O. and Laude, H., 1992, Aminopeptidase $\mathrm{N}$ is a major receptor for the entero-pathogenic coronavirus TGEV. Nature 357:417-420

Denison, M. R., 1999, The common cold. Rhinoviruses and coronaviruses. In Viral Infections of the Respiratory Tract (R. Dolin and F. P. Wright, ed.). New York, Marcel Dekker, pp. Dimitrov, D. S., 2004, Virus entry: molecular mechanisms and biomedical applications. Nat. Rev. Microbiol 2:109-122

Ding, Y., He, L., Zhang, Q., Huang, Z., Che, X., Hou, J., Wang, H., Shen, H., Qiu, L., Li, Z., Geng, J., Cai, J., Han, H., Li, X., Kang, W., Weng, D., Liang, P. and Jiang, S., 2004, Organ distribution of severe acute respiratory syndrome (SARS) associated coronavirus (SARS-CoV) in SARS patients: implications for pathogenesis and virus transmission pathways. J. Pathol. 203:622-630

Donoghue, M., Hsieh, F., Baronas, E., Godbout, K., Gosselin, M., Stagliano, N., Donovan, M., Woolf, B., Robison, K., Jeyaseelan, R., Breitbart, R. E. and Acton, S., 2000, A novel angiotensin-converting enzyme-related carboxypeptidase (ACE2) converts angiotensin I to angiotensin 1-9. Circ. Res. 87:E1-9

Drosten, C., Gunther, S., Preiser, W., van der Werf, S., Brodt, H. R., Becker, S., Rabenau, H., Panning, M., Kolesnikova, L., Fouchier, R. A., Berger, A., Burguiere, A. M., Cinatl, J., Eickmann, M., Escriou, N., Grywna, K., Kramme, S., Manuguerra, J. C., Muller, S., Rickerts, V., Sturmer, M., Vieth, S., Klenk, H. D., Osterhaus, A. D., Schmitz, H. and Doerr, H. W., 2003, Identification of a novel coronavirus in patients with severe acute respiratory syndrome. N. Engl. J. Med. 348:1967-1976

Enjuanes, L., Spaan, W., Snijder, E. and Cavanagh, D., 2000, Nidovirales. In Virus Taxonomy - Seventh Report of the International Committee for the Taxonomy of Viruses (M. H. V. Regenmortel, C. M. Fauquet, D. H. L. Bishop, E. B. Carsten, M. K. Estes, S. M. Lemon, J. Maniloff, M. A. Mayo, D. J. McGeoch, C. R. Pringle and R. B. Wickner, ed.). New York, Academic Press, pp. 835-849 
Esper, F., Shapiro, E. D., Weibel, C., Ferguson, D., Landry, M. L. and Kahn, J. S., 2005a, Association between a Novel Human Coronavirus and Kawasaki Disease. J. Infect. Dis. 191:499-502

Esper, F., Weibel, C., Ferguson, D., Landry, M. L. and Kahn, J. S., 2005b, Evidence of a novel coronavirus that is associated with respiratory tract disease in infants and young children. J. Infect. Dis. 191:492-498

Farcas, G. A., Poutanen, S. M., Mazzulli, T., Willey, B. M., Butany, J., Asa, S. L., Faure, P., Akhavan, P., Low, D. E. and Kain, K. C., 2005, Fatal severe acute respiratory syndrome is associated with multiorgan involvement by coronavirus. J. Infect. Dis. 191:193-197

Fleck, F., 2004, SARS virus returns to China as scientists race to find effective vaccine. Bull. World Health Organ. 82:152-153

Fouchier, R. A., G., H. N., Bestebroer, T. M., Niemeyer, B., de Jong, J. C., Simon, J. H. and Osterhaus, A. D., 2004, A previously undescribed coronavirus associated with respiratory disease in humans. Proc. Natl. Acad. Sci. USA 101:6212-6216

Fouchier, R. A., Kuiken, T., Schutten, M., van Amerongen, G., van Doornum, G. J., van den Hoogen, B. G., Peiris, M., Lim, W., Stohr, K. and Osterhaus, A. D., 2003, Aetiology: Koch's postulates fulfilled for SARS virus. Nature 423:240

Gallagher, T. M., 2001, Murine coronavirus spike glycoprotein. Receptor binding and membrane fusion activities. Adv. Exp. Med. Biol. 494:183-192

Gallagher, T. M. and Buchmeier, M. J., 2001, Coronavirus spike proteins in viral entry and pathogenesis. Virology 279:371-374

Gembardt, F., Sterner-Kock, A., Imboden, H., Spalteholz, M., Reibitz, F., Schultheiss, H.-P., Siems, W.-E. and Walther, T., 2005, Organ-specific distribution of ACE2 mRNA and correlating peptidase activity in rodents. Peptides, in press

Gibbs, A. J., Gibbs, M. J. and Armstrong, J. S., 2004, The phylogeny of SARS coronavirus. Arch. Virol.

Gonzalez, J. M., Gomez-Puertas, P., Cavanagh, D., Gorbalenya, A. E. and Enjuanes, L., 2003, A comparative sequence analysis to revise the current taxonomy of the family Coronaviridae. Arch. Virol. 148:2207-2235

Gorbalenya, A. E., Snijder, E. and Spaan, W. J. M., 2004, Severe acute respiratory syndrome coronavirus phylogeny: toward consensus. J. Virol. 78:7863-7866

Guan, Y., Zheng, B. J., He, Y. Q., Liu, X. L., Zhuang, Z. X., Cheung, C. L., Luo, S. W., Li, P. H., Zhang, L. J., Guan, Y. J., Butt, K. M., Wong, K. L., Chan, K. W., Lim, W., Shortridge, K. F., Yuen, K. Y., Peiris, J. S. and Poon, L. L., 2003, Isolation and characterization of viruses related to the SARS coronavirus from animals in southern China. Science 302: 276-278

Hamming, I., Timens, W., Bulthuis, M. L., Lely, A. T., Navis, G. J. and van Goor, H., 2004, Tissue distribution of ACE2 protein, the functional receptor for SARS coronavirus. A first step in understanding SARS pathogenesis. J. Pathol. 203:631-637

Harmer, D., Gilbert, M., Borman, R. and Clark, K. L., 2002, Quantitative mRNA expression profiling of ACE2, a novel homologue of angiotensin converting enzyme. FEBS Lett. 532:107-110

Hattermann, K., Muller, M. A., Nitsche, A., Wendt, S., Donoso Mantke, O. and Niedrig, M., 2005, Susceptibility of different eukaryotic cell lines to SARS-coronavirus. Arch. Virol. 150:1023-1031

He, Y., Zhou, Y., Liu, S., Kou, Z., Li, W., Farzan, M. and Jiang, S., 2004a, Receptor-binding domain of SARS-CoV spike protein induces highly potent neutralizing antibodies: implication for developing subunit vaccine. Biochem. Biophys. Res. Commun. 324: 773-781 
He, Y., Zhou, Y., Siddiqui, P. and Jiang, S., 2004b, Inactivated SARS-CoV vaccine elicits high titers of spike protein-specific antibodies that block receptor binding and virus entry. Biochem. Biophys. Res. Commun. 325:445-452

Hofmann, H., Geier, M., Marzi, A., Krumbiegel, M., Peipp, M., H., F. G., Gramberg, T. and Pöhlmann, S., 2004, Susceptibility of SARS coronavirus S protein-driven infection correlates with expression of angiotensin-converting enzyme 2 and infection can be blocked by soluble receptor. Biochem. Biophys. Res. Commun. 319:1216-1221

Hofmann, H., Pyrc, K., van der Hoek, L., Geier, M., Berkhout, B. and Pöhlmann, S., 2005, Human coronavirus NL63 employs the severe acute respiratory syndrome coronavirus receptor for cellular entry. Proc. Natl. Acad. Sci. USA, in press

Holmes, K. V. and Dveksler, G. S., 1994, Specificity of coronavirus/receptor interaction. In Cell receptors for animal viruses (E. Wimmer, ed.). Cold Spring Harbor, Cold Spring Harbor Press, pp. 403-443

Huentelman, M. J., Zubcevic, J., Hernandez Prada, J. A., Xiao, X., Dimitrov, D. S., Raizada, M. K. and Ostrov, D. A., 2004, Structure-based discovery of a novel angiotensinconverting enzyme 2 inhibitor. Hypertension 44:903-906

Jeffers, S. A., Tusell, S. M., Gillim-Ross, L., Hemmila, E. M., Achenbach, J. E., Babcock, G. J., Thomas, W. D., Jr., Thackray, L. B., Young, M. D., Mason, R. J., Ambrosino, D. M., Wentworth, D. E., Demartini, J. C. and Holmes, K. V., 2004, CD209L (L-SIGN) is a receptor for severe acute respiratory syndrome coronavirus. Proc. Natl. Acad. Sci. USA 101:15748-15753

Komatsu, T., Suzuki, Y., Imai, J., Sugano, S., Hida, M., Tanigami, A., Muroi, S., Yamada, Y. and Hanaoka, K., 2002, Molecular cloning, mRNA expression and chromosomal localization of mouse angiotensin-converting enzyme-related carboxypeptidase (mACE2). DNA Seq. 13:217-220

Koo, M., Bendahmane, M., Lettieri, G. A., Paoletti, A. D., Lane, T. E., Fitchen, J. H., Buchmeier, M. J. and Beachy, R. N., 1999, Protective immunity against murine hepatitis virus (MHV) induced by intranasal or subcutaneous administration of hybrids of tobacco mosaic virus that carries an MHV epitope. Proc. Natl. Acad. Sci. USA 96:7774-7779

Ksiazek, T. G., Erdman, D., Goldsmith, C. S., Zaki, S. R., Peret, T., Emery, S., Tong, S., Urbani, C., Comer, J. A., Lim, W., Rollin, P. E., Dowell, S. F., Ling, A. E., Humphrey, C. D., Shieh, W. J., Guarner, J., Paddock, C. D., Rota, P., Fields, B., DeRisi, J., Yang, J. Y., Cox, N., Hughes, J. M., LeDuc, J. W., Bellini, W. J. and Anderson, L. J., 2003, A novel coronavirus associated with severe acute respiratory syndrome. N. Engl. J. Med. 348: $1953-1966$

Kuiken, T., Fouchier, R. A., Schutten, M., Rimmelzwaan, G. F., van Amerongen, G., van Riel, D., Laman, J. D., de Jong, T., van Doornum, G., Lim, W., Ling, A. E., Chan, P. K., Tam, J. S., Zambon, M. C., Gopal, R., Drosten, C., van der Werf, S., Escriou, N., Manuguerra, J. C., Stohr, K., Peiris, J. S. and Osterhaus, A. D., 2003, Newly discovered coronavirus as the primary cause of severe acute respiratory syndrome. Lancet 362: 263-270

Kuo, L., Godeke, G. J., Raamsman, M. J., Masters, P. S. and Rottier, P. J., 2000, Retargeting of coronavirus by substitution of the spike glycoprotein ectodomain: crossing the host cell species barrier. J. Virol. 74:1393-1406

Lai, M. M. and Cavanagh, D., 1997, The molecular biology of coronaviruses. Adv. Virus Res. 48: $1-100$

Li, G., Chen, X. and Xu, A., 2003a, Profile of specific antibodies to the SARS-associated coronavirus. N. Engl. J. Med. 349:508-509 
Li, W., Greenough, T. C., Moore, M. J., Vasilieva, N., Somasundaran, M., Sullivan, J. L., Farzan, M. and Choe, H., 2004, Efficient replication of severe acute respiratory syndrome coronavirus in mouse cells is limited by murine angiotensin-converting enzyme 2. J. Virol. 78:11429-11433

Li, W., Moore, M. J., Vasilieva, N., Sui, J., Wong, S. K., Berne, M. A., Somasundaran, M., Sullivan, J. L., Luzuriaga, K., Greenough, T. C., Choe, H. and Farzan, M., 2003b, Angiotensin-converting enzyme 2 is a functional receptor for the SARS coronavirus. Nature 426:450-454

Li, W., Zhang, C., Sui, J., Kuhn, J. H., Moore, M. J., Luo, S., Wong, S. K., Huang, I. C., Xu, K., Vasilieva, N., Murakami, A., He, Y., Marasco, W. A., Guan, Y., Choe, H. and Farzan, M., 2005, Receptor and viral determinants of SARS-coronavirus adaptation to human ACE2. Embo J. 24:1634-1643

Lim, P. L., Kurup, A., Gopalakrishna, G., Chan, K. P., Wong, C. W., Ng, L. C., Se-Thoe, S. Y., Oon, L., Bai, X., Stanton, L. W., Ruan, Y., Miller, L. D., Vega, V. B., James, L., Ooi, P. L., Kai, C. S., Olsen, S. J., Ang, B. and Leo, Y. S., 2004, Laboratory-Acquired Severe Acute Respiratory Syndrome. N. Engl. J. Med. 350:1740-1745

Marra, M. A., Jones, S. J., Astell, C. R., Holt, R. A., Brooks-Wilson, A., Butterfield, Y. S., Khattra, J., Asano, J. K., Barber, S. A., Chan, S. Y., Cloutier, A., Coughlin, S. M., Freeman, D., Girn, N., Griffith, O. L., Leach, S. R., Mayo, M., McDonald, H., Montgomery, S. B., Pandoh, P. K., Petrescu, A. S., Robertson, A. G., Schein, J. E., Siddiqui, A., Smailus, D. E., Stott, J. M., Yang, G. S., Plummer, F., Andonov, A., Artsob, H., Bastien, N., Bernard, K., Booth, T. F., Bowness, D., Czub, M., Drebot, M., Fernando, L., Flick, R., Garbutt, M., Gray, M., Grolla, A., Jones, S., Feldmann, H., Meyers, A., Kabani, A., Li, Y., Normand, S., Stroher, U., Tipples, G. A., Tyler, S., Vogrig, R., Ward, D., Watson, B., Brunham, R. C., Krajden, M., Petric, M., Skowronski, D. M., Upton, C. and Roper, R. L., 2003, The Genome sequence of the SARS-associated coronavirus. Science 300: 1399-1404

Martina, B. E., Haagmans, B. L., Kuiken, T., Fouchier, R. A., Rimelzwaan, G. F., van Amerongen, G., Peiris, J. S., Lim, W. and Osterhaus, A. D., 2003, SARS virus infection of cats and ferrets. Nature 425:915

Marzi, A., Gramberg, T., Simmons, G., Moller, P., Rennekamp, A. J., Krumbiegel, M., Geier, M., Eisemann, J., Turza, N., Saunier, B., Steinkasserer, A., Becker, S., Bates, P., Hofmann, H. and Pöhlmann, S., 2004, DC-SIGN and DC-SIGNR interact with the glycoprotein of Marburg virus and the S protein of severe acute respiratory syndrome coronavirus. J. Virol. 78:12090-12095

Mayo, M. A., 2002, A summary of taxonomic changes recently approved by ICTV. Arch. Virol. 147:1655-1663

McIntosh, K., 2005, Coronaviruses in the Limelight. J. Infect. Dis. 191:489-491

Moore, K. M., Jackwood, M. W. and Hilt, D. A., 1997, Identification of amino acids involved in a serotype and neutralization specific epitope within the s1 subunit of avian infectious bronchitis virus. Arch. Virol. 142:2249-2256

Moore, M. J., Dorfman, T., Li, W., Wong, S. K., Li, Y., Kuhn, J. H., Coderre, J., Vasilieva, N., Han, Z., Greenough, T. C., Farzan, M. and Choe, H., 2004, Retroviruses pseudotyped with the severe acute respiratory syndrome coronavirus spike protein efficiently infect cells expressing angiotensin-converting enzyme 2. J. Virol. 78:10628-10635

Mossel, E. C., Huang, C., Narayanan, K., Makino, S., Tesh, R. B. and Peters, C. J., 2005, Exogenous ACE2 expression allows refractory cell lines to support severe acute respiratory syndrome coronavirus replication. J. Virol. 79:3846-3850 
Nie, Y., Wang, P., Shi, X., Wang, G., Chen, J., Zheng, A., Wang, W., Wang, Z., Qu, X., Luo, M., Tan, L., Song, X., Yin, X., Chen, J., Ding, M. and Deng, H., 2004, Highly infectious SARS-CoV pseudotyped virus reveals the cell tropism and its correlation with receptor expression. Biochem. Biophys. Res. Commun. 321:994-1000

Normile, D., 2004, Second Lab Accident Fuels Fears About SARS. Science 303:26

Oh, J. S., Song, D. S. and Park, B. K., 2003, Identification of a putative cellular receptor $150 \mathrm{kD}$ polypeptide for porcine epidemic diarrhea virus in porcine enterocytes. J. Vet. Sci. 4:269-275

Olsen, S. J., Chang, H. L., Cheung, T. Y., Tang, A. F., Fisk, T. L., Ooi, S. P., Kuo, H. W., Jiang, D. D., Chen, K. T., Lando, J., Hsu, K. H., Chen, T. J. and Dowell, S. F., 2003, Transmission of the severe acute respiratory syndrome on aircraft. N. Engl. J. Med. 349:2416-2422

Pearson, H., Clarke, T., Abbott, A., Knight, J. and Cyranoski, D., 2003, SARS: what have we learned? Nature 424:121-126

Pei, H., Liu, J., Cheng, Y., Sun, C., Wang, C., Lu, Y., Ding, J., Zhou, J. and Xiang, H., 2005, Expression of SARS-coronavirus nucleocapsid protein in Escherichia coli and Lactococcus lactis for serodiagnosis and mucosal vaccination. Appl. Microbiol. Biotechnol.

Peiris, J. S., Yuen, K. Y., Osterhaus, A. D. and Stohr, K., 2003, The severe acute respiratory syndrome. N. Engl. J. Med. 349:2431-2441

Pene, F., Merkat, A., Vabret, A., Rozenberg, F., Buzyn, A., Dreyfus, F., Cariou, A., Freymuth, F. and Lebon, P., 2003, Coronavirus 229E-related pneumonia in immunocompromised patients. Clin. Infect. Dis. 37:929-932

Phillips, J. J., Chua, M. M., Lavi, E. and Weiss, S. R., 1999, Pathogenesis of chimeric MHV4/MHV-A59 recombinant viruses: the murine coronavirus spike protein is a major determinant of neurovirulence. J. Virol. 73:7752-7760

Roberts, A., Vogel, L., Guarner, J., Hayes, N., Murphy, B., Zaki, S. and Subbarao, K., 2005, Severe acute respiratory syndrome coronavirus infection of golden Syrian hamsters. $J$. Virol. 79:503-511

Rota, P. A., Oberste, M. S., Monroe, S. S., Nix, W. A., Campagnoli, R., Icenogle, J. P., Penaranda, S., Bankamp, B., Maher, K., Chen, M. H., Tong, S., Tamin, A., Lowe, L., Frace, M., DeRisi, J. L., Chen, Q., Wang, D., Erdman, D. D., Peret, T. C., Burns, C., Ksiazek, T. G., Rollin, P. E., Sanchez, A., Liffick, S., Holloway, B., Limor, J., McCaustland, K., Olsen-Rasmussen, M., Fouchier, R., Gunther, S., Osterhaus, A. D., Drosten, C., Pallansch, M. A., Anderson, L. J. and Bellini, W. J., 2003, Characterization of a novel coronavirus associated with severe acute respiratory syndrome. Science 300: 1394-1399

Rowe, T., Gao, G., Hogan, R. J., Crystal, R. G., Voss, T. G., Grant, R. L., Bell, P., Kobinger, G. P., Wivel, N. A. and Wilson, J. M., 2004, Macaque model for severe acute respiratory syndrome. J. Virol. 78:11401-11404

Sanchez, C. M., Izeta, A., Sabchez-Morgado, J. M., Alonso, S., Sola, I., Balasch, M., PlanaDuran, J. and Enjuanes, L., 1999, Targeted recombination demonstrates that the spike gene of transmissible gastroenteritis coronavirus is a determinant of its enteric tropism and virulence. J. Virol. 73:7607-7618

Simmons, G., Reeves, J. D., Rennekamp, A. J., Amberg, S. M., Piefer, A. J. and Bates, P., 2004, Characterization of severe acute respiratory syndrome-associated coronavirus (SARS-CoV) spike glycoprotein-mediated viral entry. Proc. Natl. Acad. Sci. USA 101:4240-4245 
Song, C., Lee, Y., Lee, C., Sung, H., Kim, J., Mo, I., Izumiya, Y., Jang, H. and Mikami, T., 1998, Induction of protective immunity in chickens vaccinated with infectious bronchitis virus $\mathrm{S} 1$ glycoprotein expressed by a recombinant baculovirus. J. Gen. Virol. 79:719-723

Song, H. D., Tu, C. C., Zhang, G. W., Wang, S. Y., Zheng, K., Lei, L. C., Chen, Q. X., Gao, Y. W., Zhou, H. Q., Xiang, H., Zheng, H. J., Chern, S. W., Cheng, F., Pan, C. M., Xuan, H., Chen, S. J., Luo, H. M., Zhou, D. H., Liu, Y. F., He, J. F., Qin, P. Z., Li, L. H., Ren, Y. Q., Liang, W. J., Yu, Y. D., Anderson, L., Wang, M., Xu, R. H., Wu, X. W., Zheng, H. Y., Chen, J. D., Liang, G., Gao, Y., Liao, M., Fang, L., Jiang, L. Y., Li, H., Chen, F., Di, B., He, L. J., Lin, J. Y., Tong, S., Kong, X., Du, L., Hao, P., Tang, H., Bernini, A., Yu, X. J., Spiga, O., Guo, Z. M., Pan, H. Y., He, W. Z., Manuguerra, J. C., Fontanet, A., Danchin, A., Niccolai, N., Li, Y. X., Wu, C. I. and Zhao, G. P., 2005, Cross-host evolution of severe acute respiratory syndrome coronavirus in palm civet and human. Proc. Natl. Acad. Sci. USA 102:2430-2435

Subbarao, K., McAuliffe, J., Vogel, L., Fahle, G., Fischer, S., Tatti, K., Packard, M., Shieh, W. J., Zaki, S. R. and Murphy, B., 2004, Prior infection and passive transfer of neutralizing antibody prevent replication of severe acute respiratory syndrome coronavirus in the respiratory tract of mice. J. Virol. 78:3572-3577

Sui, J., Li, W., Murakami, A., Tamin, A., Matthews, L. J., Wong, S. K., Moore, M. J., Tallarico, A. S., Olurinde, M., Choe, H., Anderson, L. J., Bellini, W. J., Farzan, M. and Marasco, W. A., 2004, Potent neutralization of severe acute respiratory syndrome (SARS) coronavirus by a human $\mathrm{mAb}$ to $\mathrm{S} 1$ protein that blocks receptor association. Proc. Natl. Acad. Sci. USA 101:2536-2541

Sui, J., Li, W., Roberts, A., Matthews, L. J., Murakami, A., Vogel, L., Wong, S. K., Subbarao, K., Farzan, M. and Marasco, W. A., 2005, Evaluation of Human Monoclonal Antibody 80R for Immunoprophylaxis of Severe Acute Respiratory Syndrome by an Animal Study, Epitope Mapping, and Analysis of Spike Variants. J. Virol. 79:5900-5906

Takasuka, N., Fujii, H., Takahashi, Y., Kasai, M., Morikawa, S., Itamura, S., Ishii, K., Sakaguchi, M., Ohnishi, K., Ohshima, M., Hashimoto, S., Odagiri, T., Tashiro, M., Yoshikura, H., Takemori, T. and Tsunetsugu-Yokota, Y., 2004, A subcutaneously injected UV-inactivated SARS coronavirus vaccine elicits systemic humoral immunity in mice. Int. Immunol. 16:1423-1430

Tan, E. L., Ooi, E. E., Lin, C. Y., Tan, H. C., Ling, A. E., Lim, B. and Stanton, L. W., 2004, Inhibition of SARS coronavirus infection in vitro with clinically approved antiviral drugs. Emerg. Infect. Dis. 10:581-586

Tipnis, S. R., Hooper, N. M., Hyde, R., Karran, E., Christie, G. and Turner, A. J., 2000, A human homolog of angiotensin-converting enzyme. Cloning and functional expression as a captopril-insensitive carboxypeptidase. J. Biol. Chem. 275:33328-33243

Towler, P., Staker, B., Prasad, S. G., Menon, S., Tang, J., Parsons, T., Ryan, D., Fisher, M., Williams, D., Dales, N. A., Patane, M. A. and Pantoliano, M. W., 2004, ACE2 X-ray structures reveal a large hinge-bending motion important for inhibitor binding and catalysis. J. Biol. Chem. 279:17996-18007

van der Hoek, L., Pyrc, K., Jebbink, M. F., Vermeulen-Oost, W., Berkhout, R. J., Wolthers, K. C., Wertheim-van Dillen, P. M., Kaandorp, J., Spaargaren, J. and Berkhout, B., 2004, Identification of a new human coronavirus. Nat. Med. 10:368-373

Vickers, C., Hales, P., Kaushik, V., Dick, L., Gavin, J., Tang, J., Godbout, K., Parsons, T., Baronas, E., Hsieh, F., Acton, S., Patane, M., Nichols, A. and Tummino, P., 2002, Hydrolysis of biological peptides by human angiotensin-converting enzyme-related carboxypeptidase. J. Biol. Chem. 277:14838-14843 
Wang, P., Chen, J., Zheng, A., Nie, Y., Shi, X., Wang, W., Wang, G., Luo, M., Liu, H., Tan, L., Song, X., Wang, Z., Yin, X., Qu, X., Wang, X., Qing, T., Ding, M. and Deng, H., 2004, Expression cloning of functional receptor used by SARS coronavirus. Biochem. Biophys. Res. Commun. 315:439-444

Wentworth, D. E., Gillim-Ross, L., Espina, N. and Bernard, K. A., 2004, Mice susceptible to SARS coronavirus. Emerg. Infect. Dis. 10:1293-1296

Williams, R. K., Jiang, G. S. and Holmes, K. V., 1991, Receptor for mouse hepatitis virus is a member of the carcinoembryonic antigen family of glycoproteins. Proc. Natl. Acad. Sci. USA 88:5533-5536

Wong, S. K., Li, W., Moore, M. J., Choe, H. and Farzan, M., 2004, A 193-amino acid fragment of the SARS coronavirus $\mathrm{S}$ protein efficiently binds angiotensin-converting enzyme 2. J. Biol. Chem. 279:3197-3201

Woo, P. C. Y., Lau, S. K. P., Chu, C.-M., Chan, K.-H., Tsoi, H.-W., Huang, Y., Wong, B. H. L., Poon, R. W. S., Cai, J. J., Luk, W.-K., Poon, L. L. M., Wong, S. S. Y., Guan, Y., Peiris, J. S. M. and Yuen, K.-Y., 2005, Characterization and Complete Genome Sequence of a Novel Coronavirus, Coronavirus HKU1, from Patients with Pneumonia. J. Virol. 79: 884-895

Wu, D., Tu, C., Xin, C., Xuan, H., Meng, Q., Liu, Y., Yu, Y., Guan, Y., Jiang, Y., Yin, X., Crameri, G., Wang, M., Li, C., Liu, S., Liao, M., Feng, L., Xiang, H., Sun, J., Chen, J., Sun, Y., Gu, S., Liu, N., Fu, D., Eaton, B. T., Wang, L. F. and Kong, X., 2005, Civets are equally susceptible to experimental infection by two different severe acute respiratory syndrome coronavirus isolates. J. Virol. 79:2620-2625

Xiao, X., Chakraborti, S., Dimitrov, A. S., Gramatikoff, K. and Dimitrov, D. S., 2003, The SARS-CoV S glycoprotein: expression and functional characterization. Biochem. Biophys. Res. Commun. 3212:1159-1164

Yagil, Y. and Yagil, C., 2003, Hypothesis: ACE2 modulates blood pressure in the mammalian organism. Hypertension 41: 871-873

Yang, Z. Y., Kong, W. P., Huang, Y., Roberts, A., Murphy, B. R., Subbarao, K. and Nabel, G. J., 2004, A DNA vaccine induces SARS coronavirus neutralization and protective immunity in mice. Nature 428:561-564

Yeager, C. L., Ashmun, R. A., Williams, R. K., Cardellichio, C. B., Shapiro, L. H., Look, A. T. and Holmes, K. V., 1992, Human aminopeptidase $\mathrm{N}$ is a receptor for human coronavirus 229E. Nature 357:420-422

Yu, I. T., Li, Y., Wong, T. W., Tam, W., Chan, A. T., Lee, J. H., Leung, D. Y. and Ho, T., 2004, Evidence of airborne transmission of the severe acute respiratory syndrome virus. $N$. Engl. J. Med. 350:1731-1739

Zakhartchouk, A. N., Viswanathan, S., Mahony, J. B., Gauldie, J. and Babiuk, L. A., 2005, Severe acute respiratory syndrome coronavirus nucleocapsid protein expressed by an adenovirus vector is phosphorylated and immunogenic in mice. J. Gen. Virol. 86:211-215

Zhao, P., Cao, J., Zhao, L. J., Qin, Z. L., Ke, J. S., Pan, W., Ren, H., Yu, J. G. and Qi, Z. T., 2005, Immune responses against SARS-coronavirus nucleocapsid proteins induced by DNA vaccine. Virology 331:128-135 